Pak. j. sci. ind. res. Ser. A: phys. sci. 2019 62A(3) 157-166

\title{
Hydrocarbon Source and Reservoir Rock Potential of the Paleocene Hangu Formation in the Himalayan Foreland Basin, North West Pakistan: Insight from Geochemical and Diagenetic Study
}

\author{
Kamil Ahmed Qureshia*, Muhammad Raza Shah ${ }^{\mathrm{a}}$, Ishaque Ali Meerani ${ }^{\mathrm{b}}$, Abdul Basit ${ }^{\mathrm{a}}$, Shah \\ Fahad $^{\mathrm{a}}$, Afsar Ali Shah ${ }^{\mathrm{c}}$ and Hamid Hussain ${ }^{\mathrm{d}}$ \\ ${ }^{a}$ Department of Earth Sciences, COMSATS University, Abbottabad Campus, Pakistan \\ ${ }^{b}$ Oil and Gas Development Company Limited (OGDCL), Islamabad, Pakistan \\ ${ }^{\mathrm{c}}$ Department of Geology, University of Peshawar, Pakistan \\ ${ }^{\mathrm{d}}$ Khyber Pakhtunkhwa Oil and Gas Company Limited (KPOGCL), Peshawar, Pakistan
}

(received July 30, 2018; revised March 13, 2019; accepted March 15, 2019)

\begin{abstract}
The detail study of the Paleocene Hangu Formation consisting of sandstone, carbonaceous shale, coal, and laterite has been carried out for its source and reservoir rock potential in the Salt Range, Surghar Range, and Attock-Cherat Ranges. The TOC values of the shales range from 0.33-11.19 (2.97 wt. \%) and are characterized as good to very good quality source rock except the samples from Attock-Cherat Ranges. Similarly, the free (S1) and cracked hydrocarbons (S2) amount are very small suggesting Hangu Formation as a poor source rock for free and cracked hydrocarbons except the samples from the Lumshiwal Nala. The generative potential, type of kerogen and thermal maturity calculated on the basis of TOC, S1, S2, HI, PI and Tmax all characterized Hangu Formation as fair to excellent gas or oil source, type III and mixed type III/II kerogen and immature source rock. The Hangu Formation sandstone is brownish to yellowish brown, fine to coarse grained, medium to thick bedded and massive in places. The major diagenetic changes observed in a sandstone of the Hangu Formation are; compaction, cementation, replacement and grain fracturing. The effect of mechanical compaction is more evident than that of chemical compaction. Grain contact ranges from pointed to long through sutured. The type of cement present includes silica-cement, calcite-cement, dolomite-cement, and iron-oxide cement. Silica-cement is present as both overgrowth and pore-filling cement. Clay rim is present around few grains. The process of early calcite cementation, mechanical compaction, silica, and iron oxide cementation destroys the reservoir properties of the Hangu Formation sandstone. There is no visible porosity observed except the dissolution of few grains at their margins. However, during the process of uplifting such porosity usually filled by the ironoxide cementation. Hence, Hangu Formation is an immature source rock with a poor reservoir potential.
\end{abstract}

Keywords: Surghar Range, Paleocene, total organic carbon, thermal maturity, generative potential

\section{Introduction}

The Paleocene Hangu Formation studied in detail along the Nammal Gorge (Salt Range), Lumshiwal Nala (Surghar Range), and the Shahkot Bala Section (AttockCherat Ranges) for their source and reservoir rock potential. The Hangu Formation consists of sandstone, siltstone, carbonaceous shale, limestone, coal, and laterite (Shah, 2009). It shows variation in lithology both laterally and vertically. The stratigraphic committee of Pakistan assigned the name of Hangu Formation. The lower contact of the Hangu Formation is unconformable with the Lumshiwal Formation of the Cretaceous age in the Lumshiwal Nala (Surghar Range) and Nammal Nala (Salt Range) while in the Shahkot Bala (Attock-Cherat Ranges), the lower contact is

*Author for correspondence; E-mail: kamil_3956@yahoo.com conformable with the Kawagarh Formation. The upper contact is sharp and conformable with the Lockhart Formation in all the studied sections (Shah, 2009). Based on fauna present, the age assigned to the Hangu Formation is early Paleocene (Iqbal, 1972). However, by the presence of nanofossils, dinoflagellates and pollen and spores data, age of middle to late Paleocene have been assigned to it (Köthe et al., 1988; Danilchik and Shah, 1987). The proposed study sections at Nammal

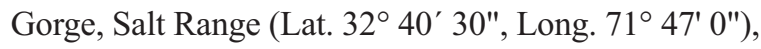
Lumshiwal Nala, Surghar Range (Lat. 32 51' 30", Long. $\left.71^{\circ} 08^{\prime} 05^{\prime \prime}\right)$ and Shahkot Bala, Attock-Cherat Ranges (Lat. 33 51' 38.97" N, Long. 71 $52^{\prime} 22.85^{\prime \prime}$ E) contain excellent exposure of the Paleocene Hangu Formation of Makarwal Group (Fig. 1). The Makarwal Group comprises of the Hangu, Lockhart and Patala Formations (Table 1). 


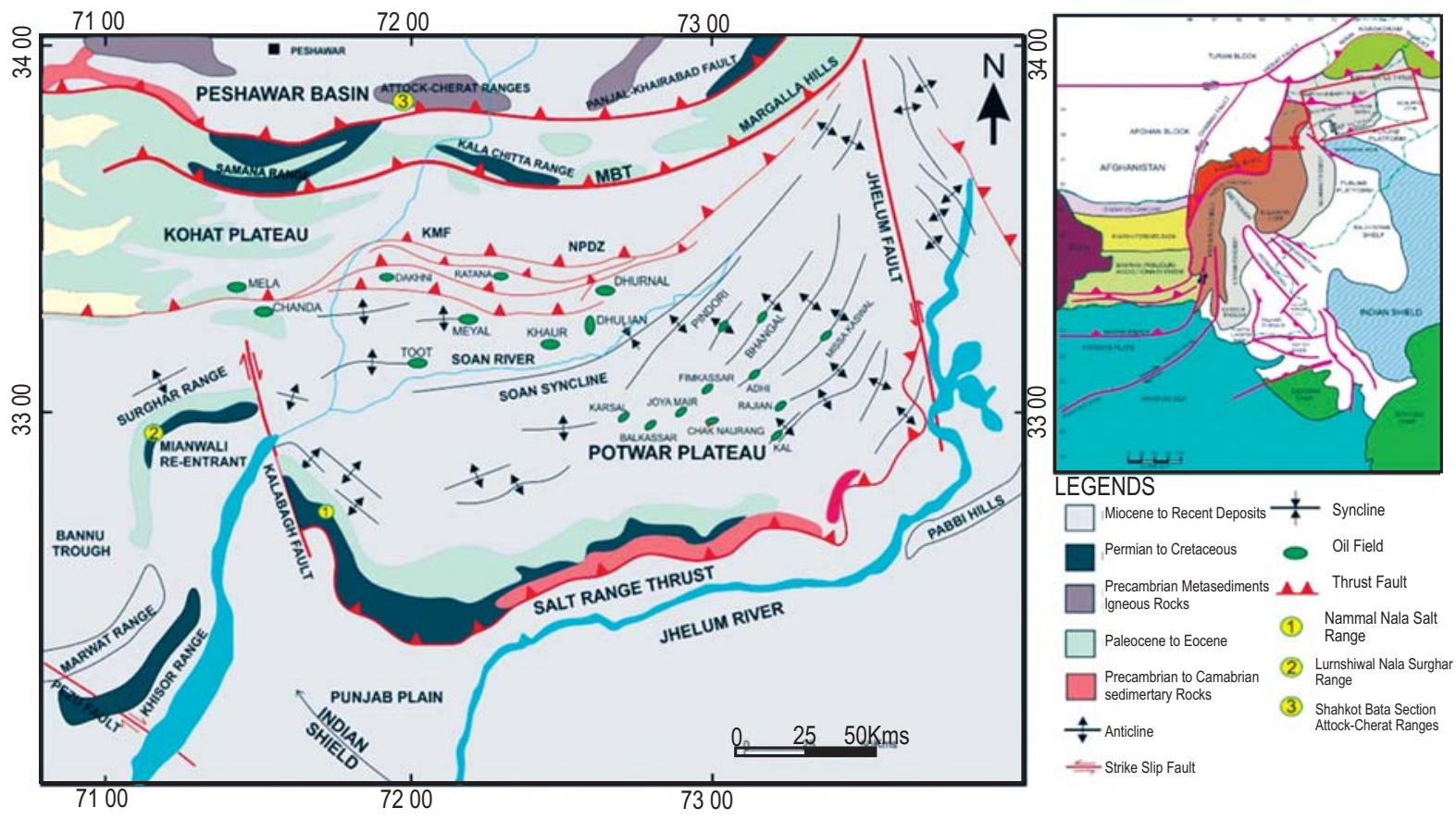

Fig. 1. Location map of the studied sections in the Salt Range, Surghar Range and the Attock-Cherat Ranges (modified after Gee and Gee, 1989).

Previously, the Hangu Formation was studied by Danilchik and Shah (1987); Simpson (1904) for the coal resources. In addition, various researchers (Ghaznavi, 1988; Abid and Abbasi, 1984) do the study describing the petrographic characteristics of the coal in the Makarwal area. Shahzad (2007) discussed the source rock potential of the Paleocene rocks in the Kohat Basin. However, no detailed work on the source and reservoir potential of the Paleocene Hangu Formation in the Salt and Trans Indus Surghar Ranges and the Attock-Cherat Ranges is available till date. This study will document for the first time the source and reservoir potential of the Hangu Formation with the help of geochemical and diagenetic data.

Regional geology of the Western Himalayas. Pakistan has a complex geological history because of a collision of Indian and Eurasian plates. The collision of these major tectonic plates resulted in Himalayan orogeny and formed major suture zones in North Pakistan, i.e. Main Karakoram Thrust (MKT) and Main Mantle Thrust (MMT). The deformation associated with Himalayan orogeny opened further thrust systems in Pakistan known as Main Boundary Thrust (MBT) and Salt Range Thrust (SRT). The Main Boundary Thrust (MBT) or Panjal-Khairabad fault divided the Himalayan fold and thrust belt into the hinterland zone, which is towards the north, and the foreland zone, which is towards the south (DiPietro et al., 1999; Pivnik and Wells, 1996).

In the foreland fold and thrust belt, Salt Range Thrust (SRT) is the youngest thrust and is formed as a result of a collision of the Indian and Eurasian plates (Jaume and Lillie, 1988). The Trans Indus Surghar Range is the southern boundary of the Kohat Basin and is the western continuation of the Salt Range (Powel, 1979). It is separated from the Salt Range by the right lateral Kalabagh strike-slip fault (McDougall and Khan, 1990). The structural trend of the Trans Indus Surghar Range is east-west and became north-south along the eastern flank of Bannu Basin (Khan and Opdyke, 1993). The foreland zone consists of Hazara-Kashmir Syntaxis, Kohat-Potwar fold belt, Salt Range and Kurram-CheratMargalla thrust belt while Himalayan crystalline nappe and thrust belt is a part of hinterland zone (Ahmad and Khan, 2012). The current study is a part of foreland zone (Fig. 1).

Sampling and geochemical analysis. The source rock potential of the Paleocene Hangu Formation was determined from nine surface samples of shales collected from the three different sections to carry out TOC and 
Table 1. Generalized stratigraphic column of the Salt Range.

\begin{tabular}{|c|c|c|c|}
\hline Era & Period & Group & Formations \\
\hline \multirow[t]{14}{*}{ Cenozoic } & \multirow[t]{3}{*}{ Pliocene } & \multirow[t]{3}{*}{ Siwalik } & Soan \\
\hline & & & Dhok Pathan \\
\hline & & & Nagri \\
\hline & \multirow[t]{3}{*}{ Miocene } & & Chinji \\
\hline & & \multirow{2}{*}{ Rawalpindi } & Kamlial \\
\hline & & & Murree \\
\hline & & \multicolumn{2}{|c|}{ Unconformity } \\
\hline & Eocene & \multirow{3}{*}{ Chharat } & Chorgali \\
\hline & & & Sakesar \\
\hline & & & Nammal \\
\hline & & \multirow[t]{3}{*}{ Makarwal } & Patala \\
\hline & Paleocene & & Lockhart \\
\hline & & & Hangu \\
\hline & \multicolumn{3}{|c|}{ Cretaceous-Tertiary Boundary } \\
\hline \multirow[t]{10}{*}{ Mesozoic } & \multirow[t]{5}{*}{ Cretaceous } & \multirow[t]{3}{*}{ Surghar } & Kawagarh \\
\hline & & & Lumshiwal \\
\hline & & & Chichali \\
\hline & & \multirow[t]{2}{*}{ Baroch } & Samana Suk \\
\hline & & & Shinawri \\
\hline & Jurassic & \multirow{4}{*}{ Musa Khel } & Datta \\
\hline & & & Kingriali \\
\hline & \multirow[t]{2}{*}{ Triassic } & & Tredian \\
\hline & & & Mianwali \\
\hline & \multicolumn{3}{|c|}{ Permo-Triassic Boundary } \\
\hline \multirow[t]{12}{*}{ Paleozoic } & \multirow[t]{7}{*}{ Permian } & \multirow[t]{3}{*}{ Zaluch } & Chhidru \\
\hline & & & Wargal \\
\hline & & & $\mathrm{Amb}$ \\
\hline & & \multirow[t]{4}{*}{ Nilawahan } & Sardhai \\
\hline & & & Warchha \\
\hline & & & Dandot \\
\hline & & & Tobra \\
\hline & & \multicolumn{2}{|c|}{ Unconformity } \\
\hline & Cambrian & \multirow[t]{4}{*}{ Jhelum } & Baghanwala \\
\hline & & & Juttana \\
\hline & & & Kussak \\
\hline & & & Khewra \\
\hline Proterozoic & \multicolumn{2}{|l|}{ Precambrian } & Salt Range \\
\hline
\end{tabular}

Rock-Eval Pyrolysis. These analyses were carried out at G \& R Laboratory of OGDCL. For TOC, rock samples were crushed and treated with hydrochloric acid to remove any trace of carbonates if present. The treated samples were then underwent oxidation to convert any carbon present into $\mathrm{CO} 2$ or $\mathrm{CO}$ at high temperature. Samples having TOC values greater than $0.5 \%$ were selected for Rock-Eval Pyrolysis following TOC and analyzed under Rock-Eval 6. During the process of pyrolysis, $100 \mathrm{mg}$ pulverized rock samples were heated in an oven under computer-controlled temperature (Behar et al., 2001). The parameters such as S1 (free hydrocarbon), S2 (cracked hydrocarbon) and S3 (expulsion of oxygen-containing compounds) were yielded during the Rock-Eval pyrolysis. Outcrop samples commonly show depletion in SI and S2 and high S3 values due to weathering (Peters, 1986). In addition, it calculated temperature (Tmax) at which maximum peak generation of S2 occurs which were used for the estimation of thermal maturity of organic matter (Hakimi et al., 2013). To evaluate the source rock potential, Rock-Eval parameters such as production index (PI), hydrogen index (HI) and oxygen index (OI) were also calculated. Weathering (oxidation) tends to remove hydrogen and add oxygen to the kerogen changing the hydrogen and oxygen index (HI vs OI) (Durand and Monin, 1980).

The reservoir potential of the Hangu Formation was determined from the 20 outcrop samples (Nammal Gorge, Lumshiwal Nala and Shahkot Bala section). Further, 15 samples were selected for thin section preparation in rock cutting laboratory at the Department of Earth Sciences, COMSATS Abbottabad. Thin sections were prepared by cutting chips and mounted on a slide made of thin glass with the help of petroproxy. The nature of grains and type of grain contacts were analyzed during diagenetic studies under the polarizing microscope at the Department of Earth Sciences, COMSATS Abbottabad.

\section{Results and Discussion}

Total organic carbon (TOC). A source rock may generate a considerable amount of hydrocarbons after the maturation of organic compound. The following are the factors necessary for the maturation of organic matter/kerogen, i.e. pressure, temperature, time and a catalyst (Bjorlykke, 2010). The TOC is a direct way to measure the organic richness of a rock and is expressed as weight percent (Peters and Cassa, 1994). If the TOC value of rock is less than $0.5 \mathrm{wt}$. \%, it is regarded as a poor source rock that does not have any potential of hydrocarbon generation (Table 2). A good source rock has a TOC value of greater than one. The TOC values of the carbonaceous shales of the Hangu Formation vary between $0.33-11.19$ with an average value of 2.97 wt. \% (Table 3). Except for the shales samples from the Attock-Cherat Ranges, all other samples show TOC values greater than 1 and are characterized as good to 
Table 2. Evaluation parameters of the source rock (after Peter et al., 2005).

\begin{tabular}{ll}
\hline \hline TOC $($ Wt. \%) & Quality of source rock \\
\hline $0.0-0.5$ & Poor \\
$0.5-1.0$ & Moderate \\
$1.0-2.0$ & Good \\
$2.0-4.0$ & Very Good \\
$4.0-$ upward & Excellent \\
\hline \hline
\end{tabular}

very good quality source rock (Table 3; Fig. 2). However, Rock-Eval pyrolysis data will further confirm the results, as TOC alone is not sufficient to characterize a rock as a good quality source rock (Selley and Sonnenberg, 2014).

Rock-Eval Pyrolysis. The information regarding the type of organic matter, its amount and thermal maturity are provided by the generative potential of the source rock, and Rock-Eval pyrolysis calculate this potential of the rocks (Makky et al., 2014; Peters, 1986) (Table 4). The S1 (free hydrocarbon) values of the Rock-Eval results range in values from $0.24-19.86 \mathrm{mg} / \mathrm{g}$ with an average value of $2.63 \mathrm{mg} / \mathrm{g}$. These values suggest a very small amount of free hydrocarbon present in a rock to act as a source free hydrocarbons except the samples from Lumshiwal Nala which shows moderate to very good potential for free hydrocarbons (Table 3 ). Hence, the shales of the Hangu Formation are poor source rock for free hydrocarbons except the shales exposed at Lumshiwal Nala. In addition, the cracked hydrocarbon (S2) values of the Rock-Eval results range from $0.16-15.6$ with an average of $3.96 \mathrm{mg} / \mathrm{g}$. The shale samples from the Salt Range and Attock-Cherat Ranges show an inadequate amount of hydrocarbons that can

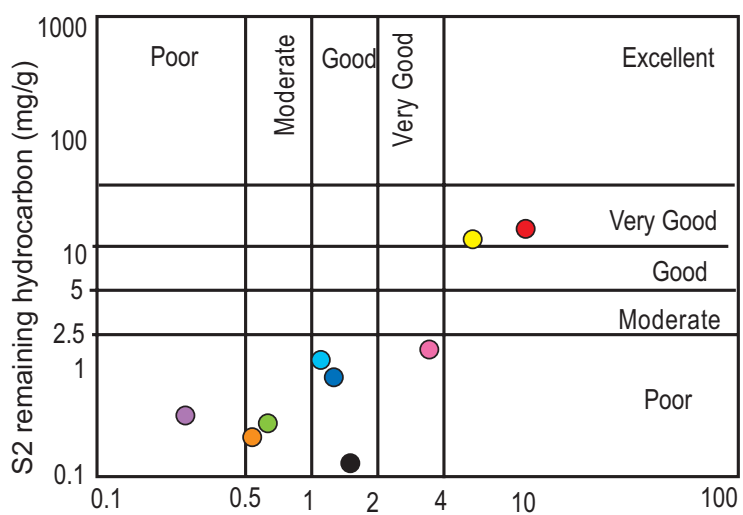

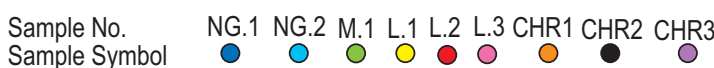

Fig. 2. TOC versus S2 depicting quality and quantity of organic matter of the Hangu Formation source rocks (after Hunt, 1995).

be released by thermal cracking of the kerogen While samples from Lumshiwal Nala shows a higher amount of cracked hydrocarbon and has a very good source rock quality (Table 3).

Source rock characteristics. The source rock characteristics that are used for the evaluation of the hydrocarbon potential of the Paleocene Hangu Formation are discussed below:

Source rock generative potential. Generative potential (GP) is a rock capability of generating free hydrocarbons during thermal maturation and can be assessed through the analysis of pyrolysis results (Hakimi et al., 2013). It is the sum of S1 and S2 values. Source rocks classified according to their GP are as follows: GP $<2$ (poor). GP 2-5 (fair), GP 5-10 (good) and GP >10 (very good) (Hunt, 1995). The data plotted on the TOC versus S1

Table 3. Geochemical analysis of the surface rocks from the Salt Range (NG), Surghar Range (L and M) and Attock-Cherat Ranges (CHR).

\begin{tabular}{|c|c|c|c|c|c|c|c|c|c|c|}
\hline Sample \# & Litho. & $\begin{array}{l}\text { TOC } \\
\text { (wt.\%) }\end{array}$ & $\mathrm{S} 1$ & $\begin{array}{l}\mathrm{S} 2 \\
\mathrm{mg} / \mathrm{g}\end{array}$ & S3 & Tmax. & $\begin{array}{l}\text { GP } \\
(\mathrm{kg} / \mathrm{T})\end{array}$ & PI & HI & OI \\
\hline NG 1 & Shale & 1.33 & 0.36 & 0.89 & 1.06 & 421 & 1.25 & 0.29 & 67 & 80 \\
\hline NG 2 & Shale & 1.19 & 0.34 & 1.22 & 1.19 & 424 & 1.56 & 0.22 & 103 & 100 \\
\hline M-1 & Shale & 0.68 & 0.33 & 0.46 & 1.02 & 431 & 0.79 & 0.42 & 68 & 150 \\
\hline L-1 & Shale & 6.06 & 1.42 & 14.58 & 13.28 & 416 & 16.0 & 0.09 & 241 & 219 \\
\hline L-2 & Shale & 11.19 & 19.86 & 15.6 & 27.84 & 408 & 175.5 & 0.11 & 202 & 249 \\
\hline L-3 & Shale & 3.81 & 0.66 & 1.83 & 4.72 & 410 & 2.49 & 0.27 & 200 & 124 \\
\hline CHR-1 & Shale & 0.56 & 0.27 & 0.40 & 0.58 & 429 & 0.67 & 0.41 & 71 & 104 \\
\hline CHR-2 & Shale & 1.65 & 0.24 & 0.16 & 2.22 & 430 & 0.40 & 0.60 & 10 & 135 \\
\hline CHR-3 & Shale & 0.33 & 0.26 & 0.51 & 0.93 & 427 & 0.77 & 0.34 & 154 & 282 \\
\hline
\end{tabular}


+ S2 plot indicate Paleocene Hangu Formation possesses fair to excellent source rock potential (Waples, 1985). The samples from the Surghar range (Lumshiwal Nala) suggest excellent source rock potential while the samples from the Cherat Ranges indicate fair source rock potential (Fig. 3a). Similarly, the Hydrogen Index (HI, mg/g) versus TOC (wt. \%) plotted data indicate Hangu Formation as a gas or oil source. Nearly all the samples fall in the field of gas or oil source (Fig. 3b).

Type of kerogen/organic matter. The current study investigates the genetic type of kerogen of the Hangu Formation as the prediction of any source rock oil and gas potential depends on the type of kerogen (Maravelis et al., 2014). The genetic type of kerogen in the Hangu Formation was determined with the help of indices such as oxygen and hydrogen, $\mathrm{S} 2$ and TOC yields. Waples (1985) discussed kerogen types classified according to their HI values (Table 5). The TOC versus S2 plot of Langford and Blanc-Valleron (1990) characterized the source rock of the Paleocene Hangu Formation as type III and mixed type III/II (Fig. 4a). The type of source rock kerogen was marked by plotting indices such as oxygen and hydrogen on Van Krevelen (1993) classification diagram. Five plotted samples represent type III kerogen while four samples lie in the field of type II (Fig. 4b).

Level of thermal maturity. Thermal maturity is an essential component of rock to act as a potential source

Table 4. Parameters for the evaluation of source rock quality based on Rock-Eval pyrolysis (after Peters and Cassa, 1994).

\begin{tabular}{lll}
\hline \hline \multicolumn{1}{l}{ S1 } & S2 & $\begin{array}{l}\text { Source rock } \\
\text { type }\end{array}$ \\
\hline$<0.5$ & & Poor \\
$0.5-1.0$ & $2.5-5$ & Moderate \\
$1.0-2.0$ & $5-10$ & Good \\
$>2.0$ & $>10$ & V. Good to Excellent \\
\hline \hline
\end{tabular}

Table 5. Types of kerogen according to their HI values (Waples, 1985).

\begin{tabular}{lll}
\hline \hline HI & Kerogen type & HC type \\
\hline$<150$ & Type III & Gas \\
$150-300$ & Type II + III & Oil + Gas \\
$>300$ & Type II & Oil + minor gas \\
$>600$ & Type I or II & Oil \\
\hline \hline
\end{tabular}
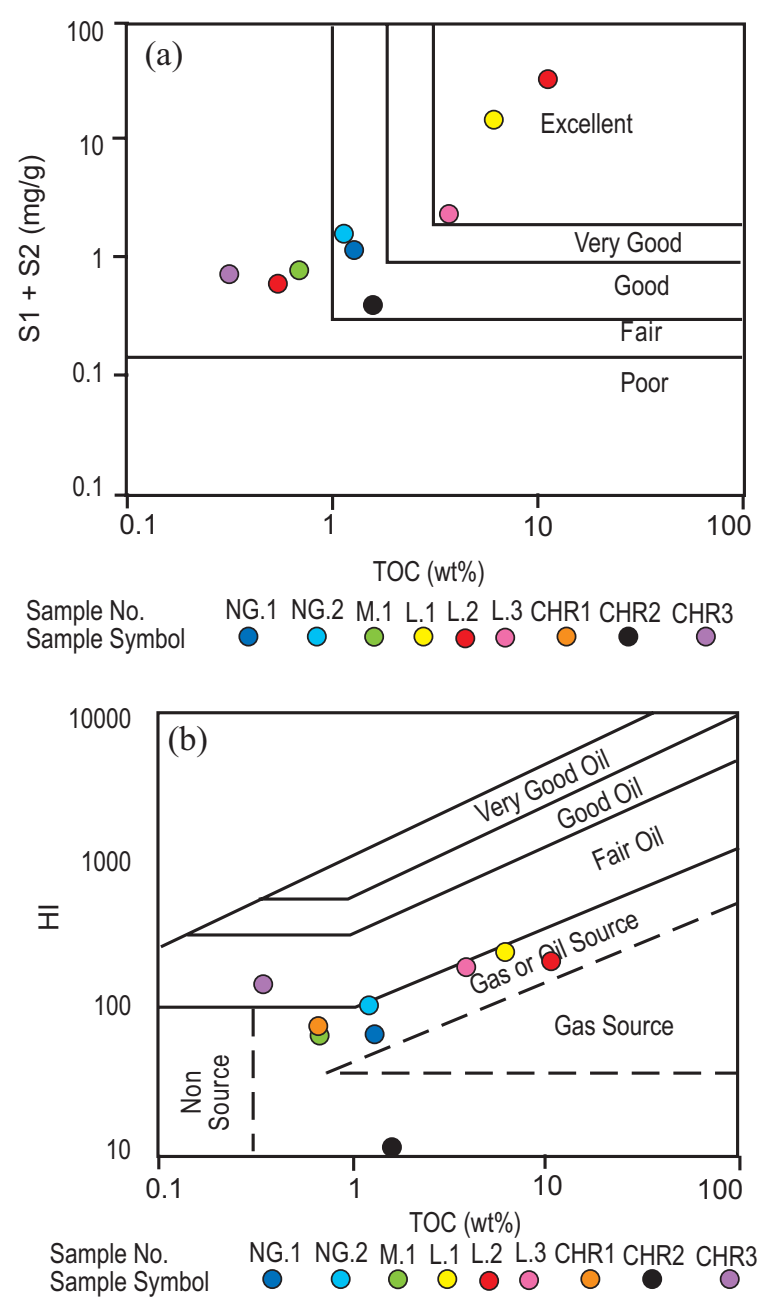

Fig. 3(a-b). Generating potentialities of the Paleocene Hangu Formation (after Waples, 1985).

rock (Makky et al., 2014) however, immature or overmature source rocks do not display any potential to generate hydrocarbons (Mashhadi et al., 2015). The thermal maturity level of the Paleocene Hangu Formation was determined by analyzing geochemical parameters such as production index (PI) and maximum temperature (Tmax) obtained from Rock-Eval data (Hunt et al., 2002). Source rock with Tmax value $<435^{\circ} \mathrm{C}$ and PI $<0.2$ is immature while the mature source rock starts oil generation at Tmax 435 Co up to 465 Co and PI from 0.2 to 0.4 (Peters, 1986; Espitalie et al., 1985). Moreover, source rock starts gas generation at Tmax $470{ }^{\circ} \mathrm{C}$ and $\mathrm{PI}>0.4$.

The type of kerogen and maturity of the source rock was determined by plotting data of the Rock-Eval 
pyrolysis in the classification diagram of Espitalie et al. (1985). The Tmax versus HI pyrolysis data fall in the field of immature source rock with some samples showing gradation to marginally mature zone and show

Table 5. Types of kerogen according to their HI values (Waples, 1985).

\begin{tabular}{lll}
\hline \hline HI & Kerogen Type & HC Type \\
\hline$<150$ & Type III & Gas \\
$150-300$ & Type II + III & Oil + Gas \\
$>300$ & Type II & Oil + minor gas \\
$>600$ & Type I or II & Oil \\
\hline \hline
\end{tabular}

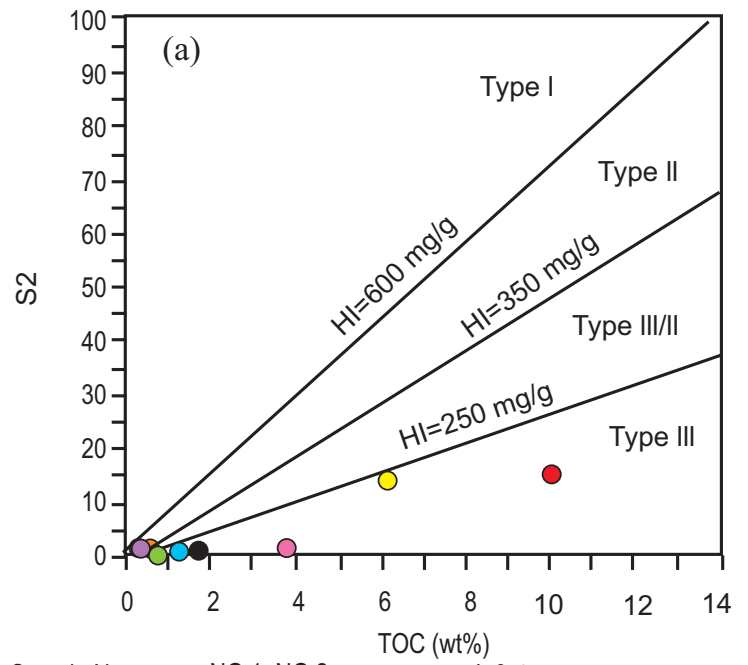

$\begin{array}{lcccccccc}\text { Sample No. } & \text { NG.1 } & \text { NG.2 } & \text { M.1 L.1 L.2 } & \text { L.3 } & \text { CHR1 } & \text { CHR2 } & \text { CHR3 } \\ \text { Sample Symbol } & 0 & 0 & 0 & O & \bigcirc & 0\end{array}$

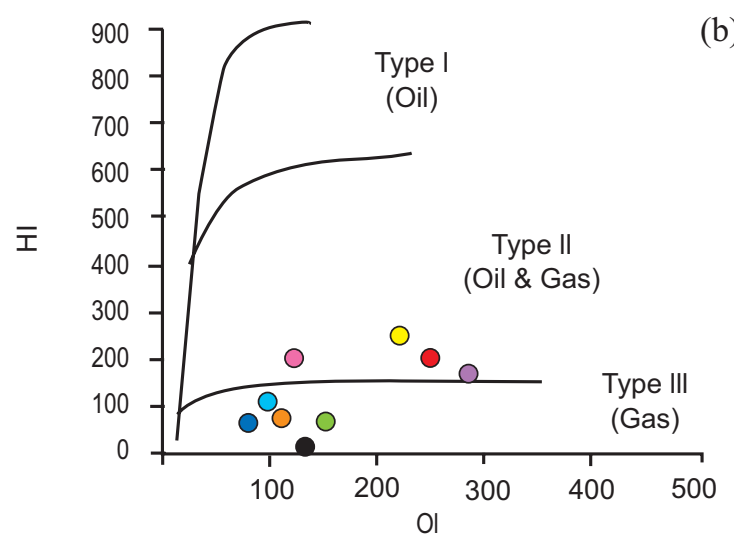

$\begin{array}{llll}\text { Sample No. NG.1 NG.2 M.1 L.1 L.2 L.3 CHR1 CHR2 CHR3 } & \text { Nample Symbol } & & \end{array}$ Sample Symbol

Fig. 4(a-b). Genetic type of kerogen/organic matter of the Hangu Formation (a: after Langford and Blanc-Valleron, 1990; b: Van Krevelen, 1993). type III kerogen (Fig. 5a). The plot (PI versus Tmax) shows that the Paleocene Hangu Formation is an immature source rock with all samples plotted in the field of stains or shows (Peters, 1986; Waples, 1985) (Fig. 5b).

Diagenesis and reservoir characteristics. Diagenesis refers to various physical, chemical, textural and mechanical post-depositional changes for the transformation of sediments into a rock (Pettijohn et al.,

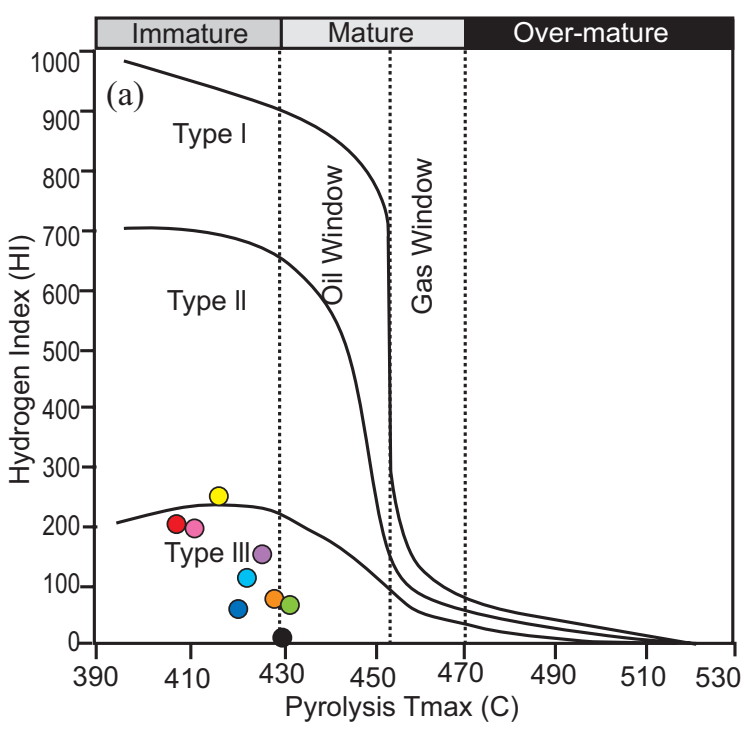

Sample No. NG.1 NG.2 M.1 L.1 L.2 L.3 CHR1 CHR2 CHR3 Sample Symbol

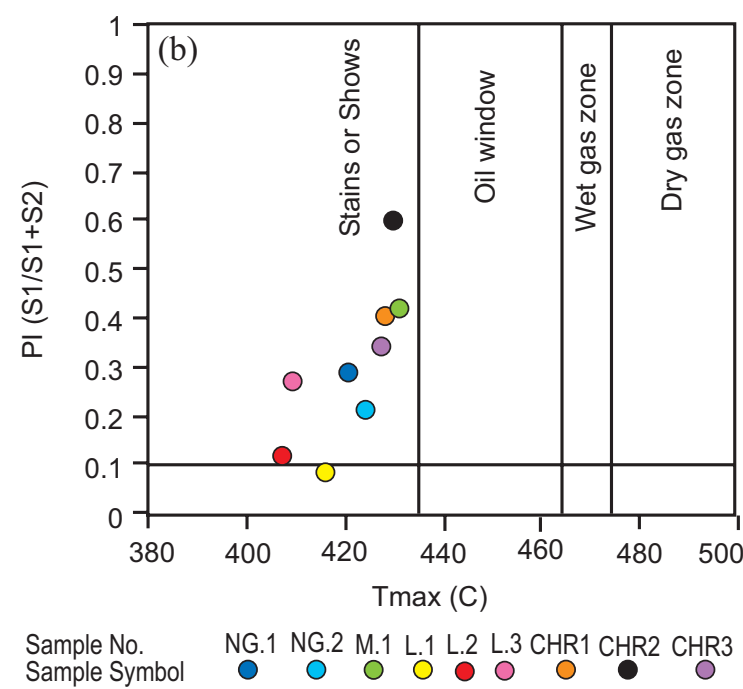

Fig. 5(a-b). Thermal maturity level of the Paleocene Hangu Formation (a: after Espitalie et al., 1985; b: Peters, 1986). 
1987). The major diagenetic changes observed in a sandstone of the Hangu Formation are compaction, cementation, replacement and grain fracturing. Compaction is the most common phenomenon observed in the Hangu Formation sandstone. Compaction is the early diagenetic phenomena results in pore water expulsion and pore volume reduction (Pittman and Larese, 1991). Because of mechanical compaction, the grains attain closer packing (pointed through sutured) and even is fractured while the chemical compaction results in grains rearrangement or dissolution (Bjorkum, 1996; Robin, 1978). The calcite-cemented samples show floating grain texture with contact ranges from pointed to elongated (Fig. 6a) however, silica-cemented samples show concavo-convex through sutured grain contact with fracturing in some brittle grains (Fig. 6b). Fractures are filled with iron oxide/ferruginous cement suggesting fracturing as an early diagenetic phase (Fig. 6d). Grain dissolution is less pronounced because of chemical compaction in the sandstone of Hangu Formation (Fig. 6f).

The type of cement present in the understudy sandstone includes silica cement, calcite cement, dolomite cement and iron oxide/ferruginous cement. Few grains have clay coating around them. Silica cement is present both as overgrowth and as pore-filling cement (Fig. 6c). Quartz overgrowth usually develops on a clean and mature sandstone at a temperature $>70{ }^{\circ} \mathrm{C}$. The higher permeability and water/silica percolation allows the clean and coarse grain sandstone to develop quartz overgrowth (Xi et al., 2015). However, the presence of clay rim around the grain margins inhibits the silica overgrowth and preserves porosity as much as $20 \%$ observed in the Cretaceous sandstone of the Sawan gas field, Pakistan (Berger et al., 2009). The possible silica source as described by Worden and Morad (2000) are; pressure dissolution, alteration of detrital feldspar, illitization and chloritization of smectite, biogenic or external source and dissolution of amorphous silica. The second type of cement observed in the sandstone of Hangu Formation is calcite. The poikilotopic calcite cement replaces other detrital grains partially or completely which display floating grains texture (Fig. 6a). The third type of cement observes is dolomite. Typical dolomite rhombs that are medium in size developed as pore occluding and grain replacing cement (Fig. 6e). The fourth cement type is the iron oxide/ferruginous that envelops grains occluding any visible porosity (Fig. 6d). Volcanic fragments, Fe-Ti

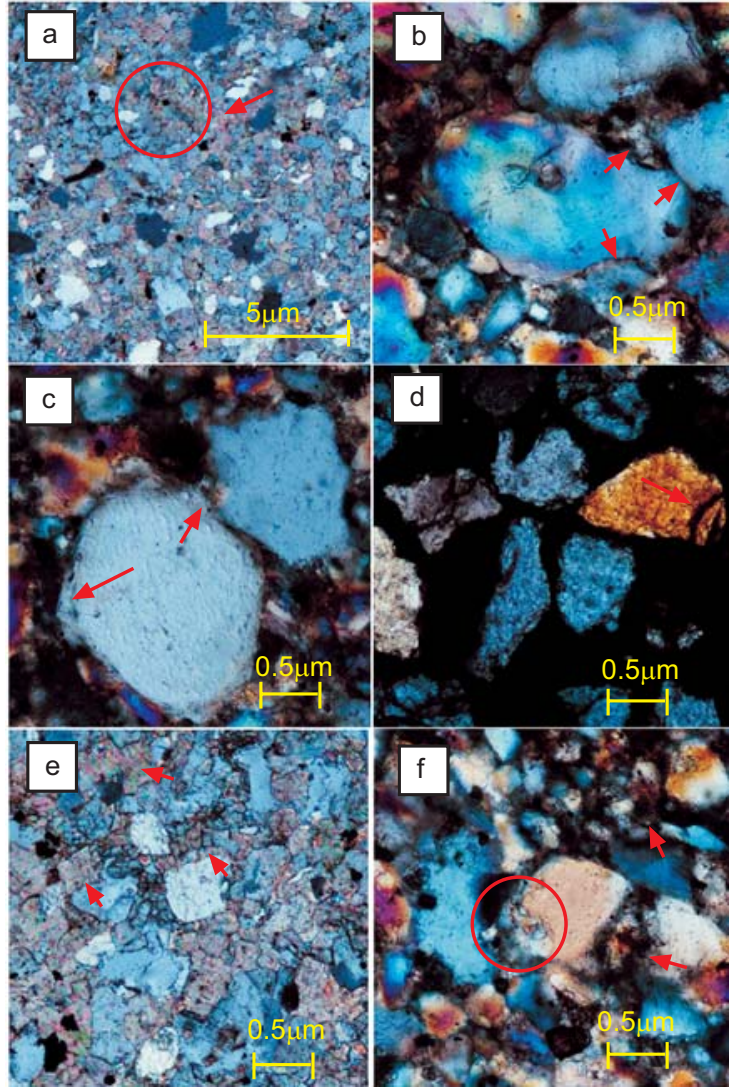

Fig. 6. Photomicrograph of the Hangu Formation sandstone diagenetic and reservoir character: a) Floating grain texture with early calcite cementation replacing grains at boundaries; b) Grains showing long to sutured contact with silica cement in the intergranular spaces and clay coating around few grains; c) Quartz overgrowth and pointed grain contact; d) Fractured grains enveloped by iron oxide; e) Calcite and dolomite cement in the intergranular pore spaces; f) Poorly sorted sediments with grain dissolution visible at the boundaries.

Oxide rich minerals, and some Fe-rich minerals may be the possible source of ferruginous cement.

The current study estimates the reservoir potential of the Paleocene Hangu Formation based on diagenetic studies and visual porosity. Reservoir characterization of sandstone refers to the amount of porosity and permeability it retained after diagenetic processes and is a function of depositional and diagenetic control (Morad et al., 2010; Cade et al., 1994). The reservoir character of sandstone is determined largely by the 
diagenetic processes such as physical compaction and authigenic cementation, which may reduce either porosity and permeability or chemical compaction (grains and cement dissolution) which enhance porosity (Ajdukiewicz and Lander, 2010; Burley and Kanotorowicz, 1986 ).

The lower part of the Hangu Formation sandstone started experiencing mechanical compaction at shallow depth however, the precipitation of the calcite cement ceases the effect of mechanical compaction as evident by the floating grains texture. The process of compaction and early calcite cementation reduces the primary porosity. The middle and top unit of the Hangu Formation Sandstone shows little or no calcite cementation undergo compaction significantly till greater depth resulting in closer grains packing (long to concavo-convex). The process of physical and chemical compaction as evident decreases the inter-granular volume (IGV) of sandstone by the tight grain packing (pressure solution). The pore spaces if the silica after the mechanical compaction fills any left cement both as pore filling and as overgrowth. The effect of chemical compaction in the form of grain dissolution is less evident in the Hangu Formation sandstone. Fracture opened because of mechanical compaction is filled by iron oxide/ferruginous cement during the process of uplifting. Hence, iron oxide/ferruginous cementation destroyed any visual porosity. Based on this, it is inferred that the Hangu Formation has poor reservoir potential.

\section{Conclusion}

The geochemical and diagenetic analysis of the Paleocene Hangu Formation to evaluate its source and reservoir potential shows that:

The source rock quality of the Hangu Formation is good to very good based on TOC values accept the shale samples from the Attock-Cherat Ranges, which are below one.

The amount of free hydrocarbons (S1) and the cracked hydrocarbons (S2) obtained from the Rock-Eval pyrolysis data suggest a poor potential for all the studied sections except the samples from the Lumshiwal Nala, which have a good quantity of free and cracked hydrocarbons that can be released by thermal cracking of the kerogen.

The generative potential of the Hangu Formation is fair to excellent and it is a good gas or oil source.
The type of kerogen of the Hangu Formation as represented by TOC, S2, HI, and OI is type III and mixed type III/II.

The thermal maturity of the Hangu Formation as deduced from the Tmax, PI, and HI categorized it as an immature source rock.

The reservoir rock potential of the Paleocene Hangu Formation as determined by the diagenetic and visual porosity characterized it as a poor reservoir rock. The process of early calcite cementation, significant mechanical compaction, silica cementation and iron oxide/ferruginous cementation during uplifting destroys all the visible porosity of the Hangu Formation sandstone.

In summary, the Paleocene Hangu Formation is an immature source rock with a poor source and reservoir rock potential.

\section{Acknowledgement}

The authors are thankful to the reviewers for their valuable comments. The authors are also thankful to the Department of Earth Sciences, COMSATS Abbottabad for providing access to the scientific instrumentation.

Conflict of Interest. The authors declare no conflict of interest

\section{References}

Ajdukiewicz, J.M., Lander, R.H. 2010. Sandstone reservoir quality prediction: The state of the art. AAPG Bulletin, 94: 1083-1091.

Abid, A.I., Abbasi, I.A. 1984. Preliminary petrography of the Hangu Sandstone. Hangu, Kohat: Peshawar, Pakistan, University of Peshawar Geological Bulletin, 17: 109-112.

Ahmad, N., Khan, M.R. 2012. Evaluation of a distinct sub-play for enhanced exploration in an emerging petroleum province, Bannu-Kohat sub-basin, Pakistan. In: American Association of Petroleum Geology, Search and Discovery Article 10391, Conference paper.

Behar, F., Beaumont, V., Penteado, H.L.D.B. 2001. Rock-Eval 6 technology: performances and developments. Oil \& Gas Science and Technology, 56: 111-134.

Berger, A., Gier, S., Krois, P. 2009. Porosity-preserving chlorite cements in shallow-marine volcaniclastic 
sandstones: Evidence from Cretaceous sandstones of the Sawan gas field, Pakistan. AAPG Bulletin, 93: 595-615.

Bjorkum, P.A. 1996. How important is pressure in causing dissolution of quartz in sandstones? Journal of Sedimentary Research, 66: 147-154.

Bjorlykke, K. 2010. Petroleum Geoscience: From Sedimentary Environments to Rock Physics. 508 pp., 1st edition Springer Verlag Berlin Heidelberg, Germany.

Burley, S.D., Kantorowicz, J.D. 1986. Thin section and SEM textural criteria for the recognition of cementdissolution porosity in sandstones. Sedimentology, 33: $587-604$.

Cade, C.A., Evans, I.J., Bryant, S.L. 1994. Analysis of permeability controls: a new approach. Clay Minerals, 29: 491-501.

Danilchik, W., Shah, S.I. 1987. Stratigraphy and coal resources of the Makarwal area, Trans-Indus mountains, Mianwali district, Pakistan. United States Geological Survey, Professional Paper; (USA), 75: 1341.

DiPietro, J.A., Pogue, K.R., Ahmad, I., Sorkhabi, R.B., Hussain, A., Quade, J., Macfarlane, A. 1999. Geologic map of the Indus syntaxis and surrounding area, northwest Himalaya, Pakistan. In: Himalaya and Tibet: Mountain Roots to Mountain Tops. ISBN: 9780813723280.

Durand, B., Monin, J.C. 1980. Elemental analysis of kerogens $(\mathrm{C}, \mathrm{H}, \mathrm{O}, \mathrm{N}, \mathrm{S}, \mathrm{Fe})$. In: Kerogen Insoluble Organic Matter from Sedimentary Rocks, pp. 113142. Editions Technip Paris, France.

Espitalie, J., Deroo, G., Marquis, F. 1985. Rock-Eval pyrolysis and its applications. Revue De L Institut Francais Du Petrole, 40: 563-579.

Gee, E. R., 1989. Overview of the geology and structure of the Salt Range, with observations on related areas of northern Pakistan. In: Tectonics of the Western Himalayas, L.L. Malinconico Jr. and R.J. Lillie(eds). Geological Society of America Special Paper, 232, pp 95-112.

Ghaznavi, M.I. 1988. The Petrographic Properties of the Coals of Pakistan. Ph.D. Thesis, 175 pp., Southern Illinois University at Carbondale, USA.

Hakimi, M. H., Abdullah, W. H., Sia, S. G., Makeen, Y. M. 2013. Organic geochemical and petrographic characteristics of Tertiary coals in the northwest Sarawak, Malaysia: implications for palaeoenvironmental conditions and hydrocarbon generation potential. Marine and Petroleum Geology, 48: 31-46.
Hunt, J.M., Philp, R.P., Kvenvolden, K.A. 2002. Early developments in petroleum Geochemistry. Organic Geochemistry, 33: 1025-1052.

Hunt, J.M. 1996. Petroleum Geochemistry and Geology, 743 pp., $2^{\text {nd }}$ edition, W. H. Freeman Company, New York, USA. ISBN 0716724413

Iqbal, M.W.A. 1972. Paleocene bivalve and gastropod fauna from Jherruk-Lakhra-Bara Nai (Sind), Salt Range (Punjab) and Samana Range (NWFP). Pakistan. Palaeontologia Pakistanica, 9: 1-105.

Jaumé, S.C., Lillie, R.J. 1988. Mechanics of the Salt Range-Potwar Plateau, Pakistan: A fold-and-thrust belt underlain by evaporites. Tectonics, 7: 57-71.

Khan, M.J., Opdyke, N.D. 1993. Position of the PaleoIndus as revealed by the magnetic stratigraphy of the Shinghar and Surghar ranges, Pakistan. In: Himalaya to the Sea: Geology, Geomorphology and the Quaternary. J.F. Schroder (ed.) pp.198212 Routledge Press, London, UK.

Köthe, A., Khan, A.M., Ashraf, M. 1988. Biostratigraphy of the Surghar Range, Salt Range, Sulaiman-Range and the Kohat area, Pakistan, according to Jurassicthrough Paleogene Calcareous Nannofossils and Paleogene-Dinoflagellates. Geological Jahrbuch, B71: 1-87.

Langford, F.F., Blanc-Valleron, M.M. 1990. Interpreting Rock-Eval pyrolysis data using graphs of pyrolizable hydrocarbons vs. total organic carbon (1). AAPG Bulletin, 74: 799-804.

Makky, A.F., El Sayed, M.I., El-Ata, A.S.A., El-Gaied, I.M.A., Abdel-Fattah, M. I., Abd-Allah, Z. M. 2014. Source rock evaluation of some upper and lower cretaceous sequences, West Beni Suef concession, Western Desert, Egypt. Egyptian Journal of Petroleum, 23: 135-149.

Maravelis, A., Makrodimitras, G., Pasadakis, N., Zelilidis, A. 2014. Stratigraphic evolution and source rock potential of a Lower Oligocene to Lower-Middle Miocene continental slope system, Hellenic Fold and Thrust Belt, Ionian Sea, northwest Greece. Geological Magazine, 151: 394-413.

Mashhadi, Z.S., Rabbani, A.R., Kamali, M.R., Mirshahani, M., Khajehzadeh, A. 2015. Burial and thermal maturity modeling of the Middle Cretaceous-Early Miocene petroleum system, Iranian sector of the Persian Gulf. Petroleum Science, 12: 367-390.

Morad, S., Al-Ramadan, K., Ketzer, J.M., De Ros, L. F. 2010. The impact of diagenesis on the heterogeneity of sandstone reservoirs: A review of 
the role of depositional facies and sequence stratigraphy. AAPG Bulletin, 94: 1267-1309.

McDougall, J. W., Khan, S.H. 1990. Strike-slip faulting in a foreland fold-thrust belt: The Kalabagh Fault and Western Salt Range, Pakistan. Tectonics, 9: 1061-1075.

Peters, K.E., Peters, K.E., Walters, C.C., Moldowan, J. M. 2005. The Biomarker Guide. vol. 1, 1655pp., Cambridge University Press, UK.

Peters, K.E., Cassa, M.R. 1994. Applied Source Rock Geochemistry: Chapter 5: In: The Petroleum System-from Source to Trap. L.B. Magoon and W.G. Dow (eds.), AAPG Memoir, 60, 93-120.

Peters, K. E. 1986. Guidelines for evaluating petroleum source rock using programmed pyrolysis. $A A P G$ Bulletin, 70: 318-329.

Pettijohn, F.J., Potter, P.E., Siever, R. 1987. Sand and Sandstone, 553pp., $2^{\text {nd }}$ edition. New York: SpringerVerlag, USA.

Pittman, E. D., Larese, R. E. 1991. Compaction of lithic sands: experimental results and applications (1). AAPG Bulletin, 75: 1279-1299.

Pivnik, D.A., Wells, N. A. 1996. The transition from Tethys to the Himalaya as recorded in northwest Pakistan. Geological Society of America Bulletin, 108: 1295-1313.

Powell, C.M. 1979. A speculative tectonic history of Pakistan and surroundings. Some constraints from the Indian Ocean In: Geodynamics of Pakistan. pp. 5-24, Geological Survey of Pakistan, Pakistan.

Robin, P. Y. F. 1978. Pressure solution at grain-to-grain contacts. Geochimica et Cosmochimica Acta, 42: 1383-1389.

Selley, R. C., Sonnenberg, S.A. 2014. Elements of Petroleum Geology 526., $3^{\text {rd }}$ edition, Academic Press, USA.

Shah, S.M.I. 2009. Stratigraphy of Pakistan; Geological Survey of Pakistan Memoirs, vol. 22, pp., 243-244, Government Pakistan, Ministry of Petroleum and Natural Resources. Pakistan.

Shahzad, A. 2007. Identification of potential hydrocarbons source rocks using biological markers in Kohat Plateau, North Pakistan. MS Thesis, National Centre of Excellence in Geology, University of Peshawar, Pakistan. 149 pp.

Simpson, R.R. 1904. Report on the coal deposits of Isa Khel. Mianwali, Punjab. Geological Survey of India Records, 31(pt 1): 9-34.

Van Krevelen, D. W.1993. Coal: Typology, Physics, Chemistry, Constitution. 979 pp., $3^{\text {rd }}$ edition, Elsevier, Amsterdam, the Netherlands.

Waples, D.W. 1985. Geochemistry in Petroleum Exploration. 232, pp., Springer, the Netherlands.

Worden, R.H., Morad, S. 2000. Quartz Cementation in Oil Field Sandstones: A Review of the Key Controversies. pp. 1-20, ISBN 97806320

Xi, K., Cao, Y., Jahren, J., Zhu, R., Bjørlykke, K., Zhang, X., Hellevang, H. 2015. Quartz cement and its origin in tight sandstone reservoirs of the Cretaceous Quantou formation in the southern Songliao basin, China. Marine and Petroleum Geology, 66: 748-763. 